\title{
FAKTOR-FAKTOR YANG MEMPENGARUHI KEPUTUSAN NASABAH MENGGUNAKAN PRODUK GADAI EMAS DI BANK SYARIAH MANDIRI KCP POLEWALI
}

\author{
Jumiarni \\ IAIN Parepare \\ jumiarni@gmail.com \\ Moh. Yasin Soumena \\ IAIN Parepare \\ mohyasinsoumena@iainpare.ac.id \\ Rusnaena \\ IAIN Parepare \\ rusnaena@iainpare.ac.id
}

\begin{abstract}
This study aims to find out if the factors that consisting of factors promotion, factors influential damage value services and factors of the decision to use the customers gold pawn in a bank syariah mandiri as well as to know whether the most commonly the influential between promotion, services and factors factors value assessment of the decision to use the customers gold pawn in a bank syariah mandiri kcp polewali .The research is quantitative research with the methods descriptive. As for the data collection was done through the distribution of the questionnaire The methodology that was used to test hypotheses is by using the practical, reliability test, normality test, of multiple regression analysis, $t$ test, test $f$ , the coefficient of determination (adjusted $r$ square), and correlations double. Based on the research done it can be seen that the regression equation is linear research and the worship of idols in this is $\mathrm{y}: 3,138+0,141 \mathrm{x} 1+0,270 \mathrm{x} 2+0,407 \times 3$, The results of the testing simultaneously ( $\mathrm{f}$ ) variable $\mathrm{x}$ consisting of the $\mathrm{x} 1$ ) (promotion, the service () $\mathrm{x} 2$, and the damage the $\mathrm{x} 3$ ( ) led to a positive and significant of the decision of customers to use the gold pawn of significantly by 0,$000 ; 0,05 \&$ it. Then, the results of the test on this fact () suggests that the variable $\mathrm{t}$ ( service $\mathrm{x} 2$ ) value assessment and the $\mathrm{x} 3$ ( ) most dominant influence simultaneously with the resolution of customers to use the gold pawn, it is spotted with significant value and $0,0000,006 ; 0,05 \&$ it .
\end{abstract}

Keywords: Factors, Decision Making, Costumer Behavior, Gold Pawn 


\section{Abstrak}

Penelitian ini bertujuan untuk mengetahui apakah faktor-faktor yang terdiri dari faktor promosi, faktor pelayanan dan faktor nilai taksiran berpengaruh terhadap keputusan nasabah menggunakan produk gadai emas di Bank Syariah Mandiri sekaligus untuk mengetahui apakah yang paling dominan berpengaruh antara faktor Promosi, faktor pelayanan dan faktor nilai taksiran terhadap keputusan nasabah menggunakan produk gadai emas di Bank Syariah Mandiri KCP Polewali. Penelitian ini merupakan penelitian kuantitatif dengan metode deskriptif. Adapun pengumpulan data dilakukan melalui penyebaran kuesioner. Metode yang digunakan untuk menguji hipotesis adalah dengan menggunakan uji validitas, uji reliabilitas, uji normalitas, analisis regresi berganda, uji T, Uji F, Koefisien Determinasi (Adjusted R Square), dan korelasi ganda. Berdasarkan hasil penelitian dapat diketahui bahwa persamaan regresi linear berganda dalam penelitan ini adalah $\mathrm{Y}: 3,138+0,141 \mathrm{X}_{1}+0,270 \mathrm{X}_{2}+0,407 \mathrm{X}_{3}$, hasil pengujian secara simultan (uji $\mathrm{F})$ variabel $\mathrm{X}$ yang terdiri dari faktor promosi $\left(\mathrm{X}_{1}\right)$, faktor pelayanan $\left(\mathrm{X}_{2}\right)$, dan faktor nilai taksiran $\left(\mathrm{X}_{3}\right)$ berpengaruh positif dan signifikan terhadap keputusan nasabah menggunakan produk gadai emas dengan nilai signifikan sebesar $0,000<0,05$. Kemudian, hasil pengujian secara parsial (uji t) menujukkan bahwa variabel faktor pelayanan $\left(\mathrm{X}_{2}\right)$ dan Faktor Nilai Taksiran $\left(\mathrm{X}_{3}\right)$ yang paling dominan berpengaruh secara simultan terhadap keputusan nasabah menggunakan produk gadai emas, hal ini terlihat dengan nilai signifikan 0,006 dan $0,000<0,05$.

Kata kunci: Faktor, Pembuatan Keputusan, perilaku konsumen, Gadai Emas. 


\section{Jumiarni, Moh. Yasin Soumena, Rusnaena}

\section{A. Pendahuluan}

Perkembangan dunia usaha dalam berbagai jenis industri seakan-akan tidak pernah pupus dengan adanya tantangan zaman. Demikian juga dengan perkembangan industri perbankan yang tidak jauh berbeda tingkat perkembangannya dengan industri-industri lainnya. Dengan menyesuaiakan zaman dan adanya kebutuhan serta masukan dari masyarakat luas, perbankan yang ada saat ini banyak mengalami perkembangan. Perkembangan ini diwujudkan dalam bentuk bervariasi baik dari segi inovasi produk, prinsip, serta sistem operasionalnya.

Dari perkembangan yang ada, dalam kurung waktu terakhir, muncul lembaga-lembaga keuangan berbasis syariah yang mana sebagai salah satu tonggak penting dalam pengembangan ekonomi syariah di Indonesia, dimana perkembangannya mengalami peningkatan yang cukup menggembirakan. Perkembangan sistem keuangan syariah semakin kuat dengan ditetapkannya dasardasar hukum operasional melalui Undang-Undang Nomor 7 Tahun 1992 tentang Perbankan yang telah diubah dalam Undang-Undang Nomor 10 Tahun 1998 Undang-Undang Nomor 23 Tahun 1999, Undang-Undang Nomor 9 Tahun 2004 tentang Bank Indonesia dan Undang-Undang Nomor 21 Tahun 2008 tentang Bank Syariah. Tentu dukungan regulasi dari pemerintah ini memberikan peluang bagi beroperasinya bank dengan sistem syariah.

Perbankan Syariah merupakan suatu badan usaha yang fungsinya sebagai penghimpun dana dari masyarakat dan menyalurkan dana kepada masyarakat, yang sistem dan mekanisme kegiatan usahanya berdasarkan hukum Islam sebagaimana yang diatur dalam al-Quran dan al-Hadist. ${ }^{1}$ Oleh karena itu, Bank Syariah Mandiri (BSM) muncul dengan layanan finansial sesuai kebutuhan nasabah dengan jangkauan termudah untuk kehidupan yang lebih bermakna. Melayani nasabah dengan pelayanan prima (service excellence) dan menawarkan beragam produk yang sesuai harapan nasabah dengan prinsip syariah.

Adapun produk gadai yang diterbitkan oleh perbankan syariah hanya produk pembiayaan gadai emas syariah. Hal tersebut dikerenakan terus meningkatkanya harga emas. Peningkatan harga tersebut disebabkan karena emas memiliki nilai instrinsik yang lebih stabil dan tahan inflasi dibandingkan mata uang kertas seperti rupiah dan dolar.

Pada tahun 2012, Bank Indonesia menerbitkan ketentuan untuk mencegah terjadinya praktik spekulasi dalam produk pembiayaan gadai emas syariah. Dalam peraturan Bank Indonesia produk gadai bank Syariah dan Unit Usaha Syariah merupakan produk pelayanan jasa berdasarkan akad qardh. Akad Qardh adalah akad atau perjanjian penyaluran dana oleh Bank Syariah dan Unit Usaha Syariah kepada nasabah sebagai utang-piutang dengan ketentuan bahwa nasabah wajib mengembalikan dana tersebut kepada Bank Syariah dan Unit Usaha Syariah pada waktu yang ditentukan. $^{2}$

\footnotetext{
${ }^{1}$ Rachmadi Usman, Aspek-aspek Hukum Perbankan Islam di Indonesian, (Bandung: PT. Citra Aditya Bakti,2002), h. 93.

${ }^{2}$ Surat Edaran Bank Indonesia Nomor 14/7/Dpbs Tentang Produk Qardh Beragunan Emas bagi Bank Syariah dan Unit Usaha Syariah
} 
Fatwa Dewan Syariah Nasional No.25/DSN-MUI/III/2002 mengatur Produk Gadai Emas Syariah. Dalam fatwa DSN No.25/DSN-MUI/III/2002 dijelaskan bahwa gadai emas diperbolehkan berdasarkan prinsip rahn dengan ketentuan-ketentuan yang telah diatur didalam Bank Syariah dan Unit Usaha Syariah. ${ }^{3}$ Ketentuan tersebut bertujuan mencegah terjadinya spekulasi dalam pratik gadai emas syariah yaitu dengan menetapkan batas maksimal plafon pembiayaan serta frekuensi perpanjangan saat jatuh tempo. Dampak dari aturan yang dikeluarkan oleh Bank Indonesia yang bekerja sama dengan DSN beragunan mengakibatkan tidak stabilnya pertumbuhan dari pembiayaan dengan menggunakan akad Qardh, salah satunya adalah produk pembiayaan pada gadai emas syariah.

Beberapa strategi perlu dilakukan oleh perbankan syariah dalam upaya menjaga pertumbuhan produk pembiayaan gadai emas syariah. Salah satunya dengan menetapkan strategi pemasaran yang efektif dan efisien. Stategi pemasaran jasa terdiri dari melakukan diffensiasi kompetitif, mengelola kualitas jasa dan mnegelola kualitas produktivitas. ${ }^{4}$ Pemasaran jasa memiliki tujuh unsur penting, yakni product, price, promotion, place, people, process, and Phisical evidenc. ${ }^{5}$ Penerapan

\footnotetext{
${ }^{3}$ Fatwa Dewan Syariah Nasional No.25/DSN-MUI/III/2002 tentang Rahn Emas.

${ }^{4}$ Fandy Tjiptono, Stategi Pemasaran,(Yogyakarta: penerbit Andi,1997), h. 143

${ }^{5}$ Rambat Lupiyoadi dan Hamdani, Manajemen Pemasaran Jasa, (Jakarta: salemba Empat, 2009), h. 70.
} 


\section{Jumiarni, Moh. Yasin Soumena, Rusnaena}

stategi pemasaran yang tepat dan efektif dapat mendorong minat nasabah dalam menggunakan produk dan jasa yang ditawarkan oleh perusahaan.

Untuk menimbulkan minat yang lebih besar terhadap suatu produk, para manajer perusahaan seharusnya melengkapi iklan mereka dengan cara promosi produk. Promosi (promotion) adalah kegiatan mengkomunikasikan informasi dari penjual ke pembeli atau dari pihak lain dalam saluran untuk mempengaruhi sikap dan perilaku. ${ }^{6}$ Oleh karena itu tugas utama manager pemasaran dalam sebuah perusahaan adalah mempromosikan atau memberitahu pelanggan (nasabah) tentang ketersediaan produk dalam peusahaannya.

Promosi merupakan faktor penentu bagi nasabah, apakah produk yang dipasarkan dapat diterima oleh masyarakat luas atau tidak. Oleh karena itu promosi memerlukan waktu yang efektif. Promosi akan sia-sia apabila tidak di komunikasikan secara efektif agar tidak terjadi kegaduhan atau kesalahpahaman. Karena tujuan utama dari promosi adalah mempengaruhi perilaku konsumen dengan cara memberitahu, membujuk dana mengingatkan.

Tujuan setiap perusahaan adalah memperoleh keuntungan yang maksimal dan mempertahankan atau bahkan berusaha meningkatkannya untuk jangka waktu lama. Tujuan tersebut dapat direalisasi apabila promosi dapat dilaksanakan seperti yang direncanakan. Untuk mencapai tujuan tersebut Bank Syariah Mandiri KCP Polewali telah melakukan usaha agar produk dan jasanya digunakan oleh nasabah. Inovasi dalam pemasaran dapat mempengaruhi keberhasilan suatu perusahaan secara langsung melalui peningkatan penjualan, melalui terobosan dalam media periklanan, semboyan atau saluran pemasaran serta sarana promosi yang lainnya. Oleh karena itu, promosi merupakan sarana yang paling ampuh untuk menarik dan mempertahankan nasabah. ${ }^{7}$

Walaupun promosi bukan satu-satunya cara untuk meningkatkan minat masyarakat untuk menjadi nasabah, tetapi cukup punya andil dalam mempengaruhi pencapaian target yang diinginkan. Untuk itu promosi harus dilaksanakan dengan cara sera media yang tepat dan sesuai sehingga promosi menjadi efektif dan diharapkan dapat mecapai sasaran dalam upaya meningkatkan minat nasabah dalam pemilihan produk gadai emas.

Selain promosi, faktor harga juga mempengaruhi minat nasabah dalam memilih produk perbankan syariah dalam hal ini gadai emas. Dalam penelitian ini harga dimasukkan ke dalam variabel harga taksiran barang karena penelitian ini tentang produk gadai emas. Harga taksiran barang merupakan penetapan nilai rupiah atas gadai emas berdasarkan formulasi perkiraan harga yang ditetapkan. Apabila harga taksiran ini tinggi maka hal ini juga berpengaruh terhadap minat nasabah yang meningkat.

Nilai taksiran yang tinggi mampu mendorong keputusan nasabah menggunakan produk gadai emas. Nasabah akan merespon positif apabila nilai yang dihasilkan dari produk dan jasa mampu memenuhi manfaat bagi kebutuhannya. ${ }^{8}$ Bank syariah harus mampu mengembangkan nilai tambah

\footnotetext{
${ }_{7}^{6}$ E. Jerome McCarthy, Dasar-Dasar Pemasaran, (Jakarta: Erlangga, 1993), h. 293.

M. Nur Rianto Al-Arif, Dasar-Dasar Pemasaran Bank Syariah, (Bandung: Alfabeta, 2010), h. 169.

${ }^{9}$ Rambat Lupiyoadi dan A. Hamdani, Manajemen Pemasaran Jasa, (Jakarta: Salemba Empat, 2006), h. 70.
} 
dari produk gadai yang ditawarkan dan bank syariah harus memberikan perbedaan antara produk gadai syariah dengan produk gadai lainnya.

Faktor kualitas pelayanan kepada nasabah juga sangat penting dalam pemasaran jasa. Kualitas pelayanan adalah tingkat keunggulan yang diharapkan dan pengendalian atas tingkat keunggulan tersebut untuk memenuhi keinginan pelanggan. ${ }^{9}$ Kehandalan sistem pelayanan menjadi penentu atas kepercayaan nasabah untuk memilih jasa

Peneliti memilih produk pembiayaan gadai di perbankan syariah karena gadai syariah merupakan pembiayaan yang memberikan solusi untuk memperoleh dana tunai dalam keperluan modal usaha dengan proses cepat, mudah, aman dan sesuai syariah. Produk gadai di perbankan syariah merupakan fasilitas pinjaman dana untuk keperluan mendesak dan dalam jangka pendek serta sesuai syariah tanpa adanya tambahan margin dengan syarat menggadaikan barang berharga yang telah dimilikinya sebagai jaminan atas pinjamannya termasuk pemberian fasilitas penyimpanan dan pemeliharaan barang berharga kepada nasabah. ${ }^{10}$ Intinya gadai di Bank Syariah Mandiri merupakan pembiayaan yang paling tepat untuk dipilih ketika kita membutuhkan dana di saat yang cepat, yaitu hanya dengan meggadaikan barang yang kita miliki kepada pihak Bank Syariah Mandiri.

\footnotetext{
${ }^{9}$ Fandy Tjiptono, Perspektif Manajemen dan Pemasaran Kontemporer, Cet. Pertama, (Yogyakarta: Andi Offset, 2007), h. 59.

${ }^{10}$ Surat Edaran No. SE: S. 022-DIR/MDM/05-2013 Tentang Petunjuk Pelaksanaan Qardh Beragun. Jakarta, 3 Mei 2013.
} 


\section{Jumiarni, Moh. Yasin Soumena, Rusnaena}

Selain itu praktik gadai telah ada sejak zaman Rasulullah saw. dan beliau pernah melakukannya. Nabi saw. hendak menggadaikan baju besi beliau kepada orang Yahudi untuk berutang gandum kepadanya.

Dalam peneliti kali ini, penulis memilih Bank Syariah Mandiri KCP Polewali sebagai obyek penelitian karena merupakan salah satu perusahaan perbankan yang mengaplikasikan sistem syariah (dual banking system). Kemudian, pada observasi awal penulis melakukan interview kepada salah satu pegawai dan dia mengatakan bahwa nasabah yang memilih produk gadai emas itu kurang lebih 1.000 nasabah baik yang ada didalam maupun yang diluar kota Polewali dan yang menjadi nasabah Yaitu PNS, Wiraswasta, IRT dan lain-lain.

\section{B. Metode, Analisis Data dan Pembahasan}

\section{Pengujian Instrumen Penelitian}

a. Uji Validitas Data

Validitas menunjukkan sejauh mana alat pengukur yang dipergunakan untuk mengukur apa yang diukur. Pengujian validitas dilakukan dengan bantuan komputer menggunakan program SPSS for Windows Versi 21. Uji validitas data variabel faktor-faktor yang mempengaruhi keputusan nasabah menggunakan produk gadai emas di Bank Syariah Mandiri dengan penelitian ini pengujian validitas hanya dilakukan terhadap 100 responden. Pengambilan keputusan berdasarkan pada nilai $\mathrm{r}_{\text {hitung }}$ (Pearson Correlation) $>\mathrm{r}_{\text {tabel }}$ sebesar 0,165 maka item pernyataan dinyatakan valid pada tingkat signifikansi $\alpha=5 \%$.

Adapun hasil uji validitas dari setiap variabel dalam penelitian ini sebagai berikut :

\section{Tabel 1}

\section{Correlations}

\begin{tabular}{|c|c|c|c|c|c|c|}
\hline & & $\begin{array}{c}\text { Jawaban_ } \\
\text { X1 }\end{array}$ & $\begin{array}{c}\text { Jawaban_ } \\
\text { X2 }\end{array}$ & $\begin{array}{c}\text { Jawaban_ } \\
\text { X3 }\end{array}$ & $\begin{array}{c}\text { Jawaban_ } \\
\text { Y }\end{array}$ & $\begin{array}{c}\text { Total_Jawaba } \\
\mathrm{n}\end{array}$ \\
\hline \multirow{6}{*}{ Jawaban_X1 } & Pearson & 1 & .166 & $.598^{* *}$ & $.456^{* *}$ & $.689^{* *}$ \\
\hline & Correlation & & & & & \\
\hline & Sig. (2- & & .099 & .000 & .000 & .000 \\
\hline & tailed) & & & & & \\
\hline & $\mathrm{N}$ & 100 & 100 & 100 & 100 & 100 \\
\hline & Pearson & .166 & 1 & $.591^{* *}$ & $.557^{* *}$ & $.723^{* *}$ \\
\hline \multirow{4}{*}{ Jawaban_X2 } & Correlation & & & & & \\
\hline & Sig. (2- & .099 & & .000 & .000 & .000 \\
\hline & tailed) & & & & & \\
\hline & $\mathrm{N}$ & 100 & 100 & 100 & 100 & 100 \\
\hline
\end{tabular}


Faktor-faktor Gadai Emas

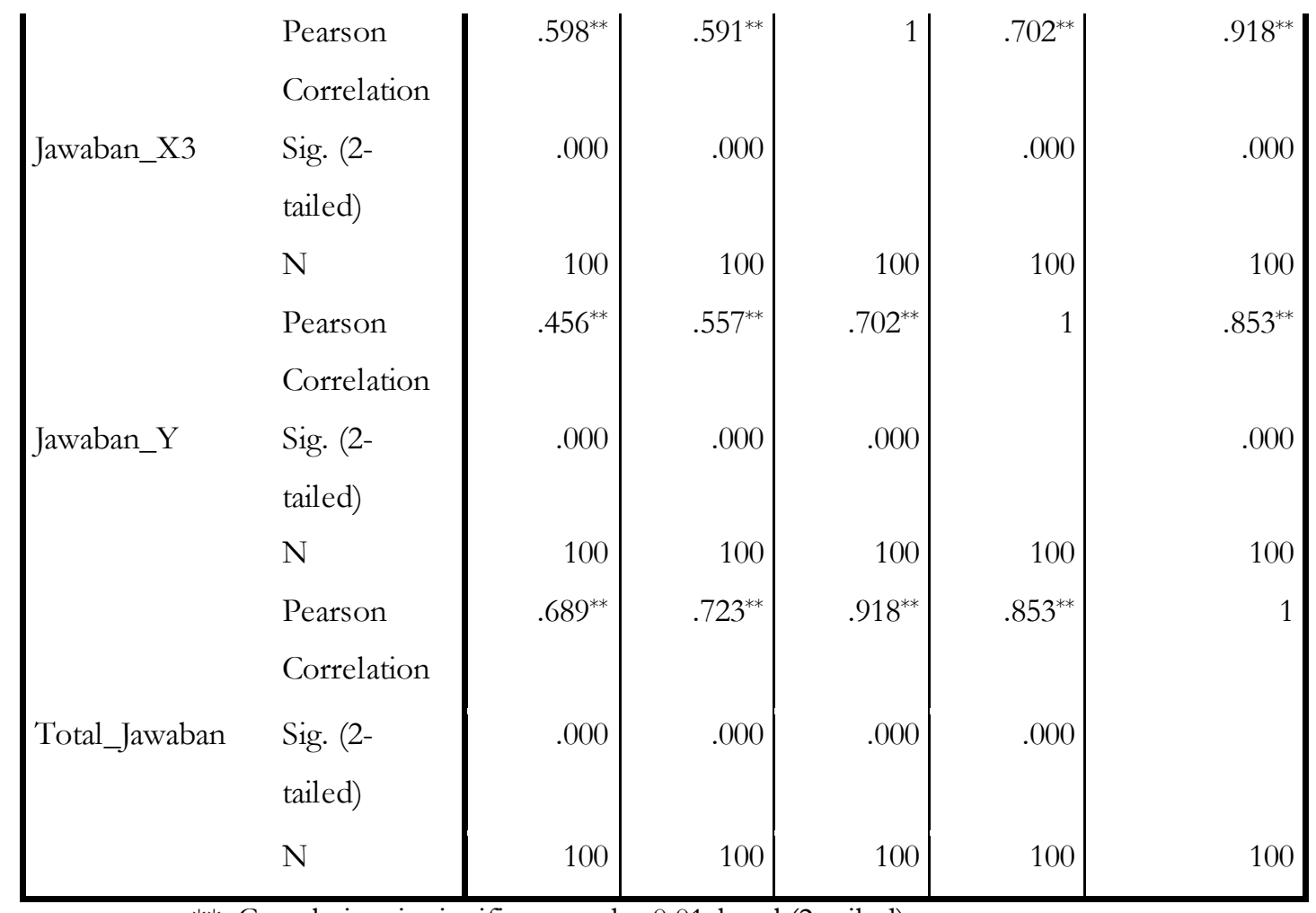

**. Correlation is significant at the 0.01 level (2-tailed).

Banco, Volume 1, Mei 2019 


\section{Jumiarni, Moh. Yasin Soumena, Rusnaena}

*. Correlation is significant at the 0.05 level (2-tailed).

Dasar Pengambilan keputusan:

Jika $\mathrm{r}_{\text {hitung }}>\mathrm{r}_{\text {tabel }}=$ valid

Jika $\mathrm{r}_{\text {hitung }}<\mathrm{r}_{\text {tabel }}=$ tidak valid

Hasil uji validitas dari keempat butir pernyataan variabel faktor promosi di peroleh Corrected Item Total Corelatioan $\mathrm{r}_{\text {hitung }} 0,689>\mathrm{r}_{\text {tabel }} 0,165$ pada tingkat signifikansi $\alpha=5 \%$. Hal ini berarti setiap butir pernyataan dari variabel faktor promosi yang digunakan dalam penelitian ini adalah valid.

Hasil uji validitas dari keempat butir pernyataan variabel belajar di peroleh Corrected Item Total Corelatioan $\mathrm{r}_{\text {hitung }} 0,723>\mathrm{r}_{\text {tabel }} 0,173$ pada tingkat signifikansi $\alpha=5 \%$. Hal ini berarti setiap butir pernyataan dari variabel faktor pelayanan yang digunakan dalam penelitian ini adalah valid.

Hasil uji validitas dari keempat butir pernyataan variabel faktor nilai taksiran di peroleh Corrected Item Total Corelatioan $\mathrm{r}_{\text {hitung }} 0,918>\mathrm{r}_{\text {tabel }} 0,173$ pada tingkat signifikansi $\alpha=5 \%$. Hal ini berarti setiap butir pernyataan dari variabel sikap yang digunakan dalam penelitian ini adalah valid.

Hasil uji validitas dari keempat butir pernyataan variabel nasabah menggunakan produk gadai emas di peroleh Corrected Item Total Corelatioan $\mathrm{r}_{\text {hitung }} 0,853>\mathrm{r}_{\mathrm{tabel}}$ 0,165 pada tingkat signifikansi $\alpha=5 \%$. Hal ini berarti setiap butir pernyataan dari variabel persepsi yang digunakan dalam penelitian ini adalah valid.

b. Uji Reliabilitas

Uji reliabilitas dilakukan terhadap item pertanyaan yang dinyatakan valid. suatu variabel dikatakan reliabel atau handal jika jawaban terhadap pernyataan selalu konsisten. Koefisien reliabilitas instrumen dimaksudkan untuk melihat konsistensi jawaban butir-butir pernyataan yang diberikan oleh responden. Uji reliabilitas bertujuan untuk mengetahui sejauh mana hasil pengukuran tetap konsisten, apabila dilakukan pengukuran dua kali atau lebih terhadap gejala yang sama dengan menggunakan alat pengukur yang sama pula. Uji reliabilitas data dilakukan dengan dibantu komputer program SPSS Versi 21.

Adapun hasil uji reliabilitas dari setiap item pertanyaan variabel yang digunakan dalam penelitian ini sebagai berikut:

\section{Tabel 2}

\section{Hasil Uji Reliabilitas}

\section{Reliability Statistics}

\begin{tabular}{|c|c|}
\hline $\begin{array}{c}\text { Cronbach's } \\
\text { Alpha }\end{array}$ & N of Items \\
\hline
\end{tabular}




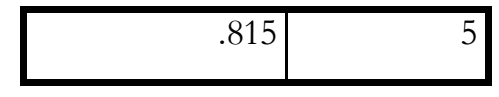

Dasar pengambilan keputusannya :

Jika alpha $>\mathrm{r}_{\text {tabel }}=$ konsisten

Jika alpha $<\mathrm{r}_{\text {tabel }}=$ tidak konsisten

Berdasarkan tabel diatas, uji reliabilitas dari setiap item instrumen terhadap semua variabel diperoleh nilai Cronbach's Alpha ( $\mathrm{r}$ hitung) 0,815> nilai $\mathrm{r}_{\text {tabel }}=0,173$ pada tingkat signifikan $\alpha=5 \%$, maka instrumen pernyataan memiliki reliable yang tinggi. Jadi, uji instrumen data pada semua variabel sudah valid dan reliable untuk seluruh butir instrumennya, maka dapat digunakan untuk pengukuran data dalam rangka pengumpulan data.

\section{c. Pengujian Asumsi Klasik}




\section{Jumiarni, Moh. Yasin Soumena, Rusnaena}

1) Uji Normalitas

Analisis statistik yang digunakan untuk menguji hipotesis penelitian ini adalah korelasi product moment. Sebelum menganalisis data yang diperoleh, data harus memenuhi persyaratan uji analisis yang digunakan. Analisis korelasi yang mensyaratkan harus berdistribusi normal. Untuk itu, perlu di uji normalitas datanya, penulis menggunakan program SPSS versi 21 dengan rumus One-Sample Kolmogorov-Smirnov Test sebagai berikut:

Tabel 3

Uji Normalitas Dengan Menggunakan Analisis Kolmogorov-Smirnov Test One- Sample Kolmongorov-Smirnov Test One-Sample Kolmogorov-Smirnov Test

\begin{tabular}{|ll|r|}
\hline & & $\begin{array}{r}\text { Unstandardize } \\
\text { d Residual }\end{array}$ \\
\hline $\mathrm{N}$ & Mean & 100 \\
Normal Parametersa,b & Std. Deviation & .0000000 \\
& Absolute & 1.13224431 \\
Most Extreme & Positive & .080 \\
Differences & Negative & .080 \\
Kolmogorov-Smirnov Z & & -.040 \\
Asymp. Sig. (2-tailed) & & .797 \\
\end{tabular}

a. Test distribution is Normal.

b. Calculated from data.

Ha : Data berdistribusi normal

Ho : Data tidak berdistribusi normal

Dasar Pengambilan keputusan:

Jika sign. $>0,05=$ normal

Jika sign. $<0,05=$ tidak normal

Karena nilai signifikan (2-tailed) 0,549>0,05 pada tingkat signifikan $\alpha=5 \%$, maka Ha diterima, hal ini berarti bahwa distribusi frekuensi taksiran berasal dari populasi yang berdistribusi normal.

2) Uji Multikolinearitas 
Dengan uji multikolinearitas digunakan untuk mengetahui gejala korelasi antar variabel bebas yang ditunjukkan dengan korelasi yang signifikan antar variabel bebas. Uji multikolinearitas bertujuan untuk menguji apakah korelasi antara variabel bebas dalam penelitian ini. Model yang baik adalah model yang tidak terdapat korelasi antara variabel bebas. Untuk mendeteksi ada tidaknya multikolinearitas di dalam model regresi adalah dengan melihat nilai toleransi dan Variance Inflation Factor (VIF). Apabila nilai toleransi $>0,1$ dan VIF $<10,0$, maka dapat disimpulkan tidak ada multikolinearitas antar variabel bebas dalam model regresi ini.Adapun hasil perhitungan nilai VIF atau toleransi yang dilakukan untuk regresi dalam penelitian ini dapat dilihat pada sebagai berikut :

Tabel 4

\section{Uji Multikolinearitas}

Coefficients $^{a}$

\begin{tabular}{|c|c|c|c|c|c|c|c|}
\hline \multirow[t]{2}{*}{ Model } & \multicolumn{2}{|c|}{$\begin{array}{l}\text { Unstandardized } \\
\text { Coefficients }\end{array}$} & \multirow{2}{*}{$\begin{array}{c}\text { Standardize } \\
\mathrm{d} \\
\text { Coefficients } \\
\text { Beta }\end{array}$} & \multirow[t]{2}{*}{$\mathrm{t}$} & \multirow[t]{2}{*}{ Sig. } & \multicolumn{2}{|c|}{$\begin{array}{l}\text { Collinearity } \\
\text { Statistics }\end{array}$} \\
\hline & B & Std. Error & & & & Tolerance & VIF \\
\hline
\end{tabular}




\section{Jumiarni, Moh. Yasin Soumena, Rusnaena}

\begin{tabular}{|rl|r|r|r|r|r|r|r|}
\hline & (Constant) & 3.138 & 1.660 & & 1.891 & .062 & & \\
& Promosi & .141 & .098 & .131 & 1.447 & .151 & .589 & 1.699 \\
& Pelayanan & .270 & .095 & .256 & 2.835 & .006 & .596 & 1.679 \\
& NilaiTaksir & .407 & .096 & .472 & 4.253 & .000 & .394 & 2.540 \\
\hline
\end{tabular}

a. Dependent Variable: Keputusan Nasabah Menggunakan Produk Gadai Emas

Hasil uji Multikolinearitas pada tabel di atas, menunjukkan bahwa semua variabel memiliki nilai VIF yang lebih kecil dari 10,00 dan nilai tolenransi yang lebih besar dari 0,10. Hal ini menunjukkan bahwa indikasi keberadaan multikolinearitas pada persamaan yang dilakukan tidak terbukti atau tidak terdapat multikolinearitas dalam persamaan yang dilakukan atau hubungan yang terjadi antar variabel bebas (faktor promosi, faktor pelayanan dan faktor nilai taksiran) dapat ditoleransi sehingga tidak akan mengganggu hasil regresi.

\section{Analisis Data}

\section{a. Analisis Regresi Berganda}

Berdasarkan hasil asumsi klasik yang meliputi uji normalitas, dan uji multikolinearitas menunjukkan bahwa regresi berganda yang distimasi telah memenuhi syarat asumsi-asumsi klasik sehingga diharapkan hasilnya akan baik dalam menganalisis faktor-faktor yang mempengaruhi keputusan nasabah menggunakan produk gadai emas di Bank Syariah Mandiri. Pengujian terhadap agresi yang diperoleh dilakukan pengujian secara simultan dengan menggunakan uji-F dan pengujian secara parsial dengan menggunakan uji-t, untuk lebih jelasnya akan diuraikan sebagai berikut .

Pada analisa data diperlukan suatu persamaan garis bedasarkan suatu rumus matematika yang menunjukkan hubungan antara variabel independen atau yang mempengaruhi dengan variabel dependen atau variabel yang dipengaruhi. Variabel yang mempengaruhi disebut varibel $\mathrm{X}_{1}, \mathrm{X}_{2}$, dan $\mathrm{X}_{3}$ dan variabel yang dipengaruhi disebut variabel $\mathrm{Y}$.

Untuk mengetahui pengaruh-pengaruh antara variabel-variabel tersebut dalam penelitian ini digunakan alat regresi. Regresi menunjukkan hubungan antara variabel-variabel yang satu dengan variabel yang lain dimana variabel yang satu mempengaruhi variabel yang lain. Analisis regresi linear berganda digunakan untuk mengetahui ada atau tidaknya faktor-faktor yang mempngaruhi keputusan nasabah menggunakan produk gadai emas di Bank Syariah Mandiri. Teknik ini digunakan untuk pengujian terhadap ada tidaknya pengaruh atau hubunga antara variabel dalam penelitian ini.

Adapun persamaan Regresi Linear Berganda adalah sebagai berikut :

$Y=a+\beta_{1} X_{1}+\beta_{2} X_{2}+\beta_{3} X_{3}$

Dimana : 
Y : Keputusan nasabah menggunakan produk gadai emas di BSM (Variabel yang dependen atau nilai yang diprediksikan)

$\mathrm{X}_{1} \quad$ : Faktor promosi (Variabel independen atau variabel yang mempengaruhi variabel dependen)

$\mathrm{X}_{2} \quad$ : Faktor pelayanan (Variabel independen atau variabel yang mempengaruhi variabel dependen)

$\mathrm{X}_{3}$ : Faktor nilai taksiran (Variabel independen atau variabel yang mempengaruhi variabel dependen)

a : Konstanta (nilai yang tidak berubah)

Analisis regresi linear berganda digunakan untuk mengetahui besarnya pengaruh variabel independen yaitu faktor promosi, faktor pelayanan dan faktor nilai taksiran terhadap variabel dependen yaitu keputusan nasabah menggunakan produk gadai di BSM, digunakan regresi linear berganda. Berdasarkan hasil olahan data yang dilakukan dengan program SPSS versi 21, maka didapatkan hasil regresi linear berganda sebagai berikut : 
Tabel 5

Coefficients $^{a}$

\begin{tabular}{|c|c|c|c|c|c|c|}
\hline \multirow{2}{*}{\multicolumn{2}{|c|}{ Model }} & \multicolumn{2}{|c|}{ Unstandardized Coefficients } & \multirow{2}{*}{$\begin{array}{l}\text { Standardized } \\
\text { Coefficients } \\
\text { Beta }\end{array}$} & \multirow[t]{2}{*}{$\mathrm{t}$} & \multirow[t]{2}{*}{ Sig. } \\
\hline & & B & Std. Error & & & \\
\hline \multirow{4}{*}{1} & (Constant) & 3.138 & 1.660 & & 1.891 & .062 \\
\hline & Promosi & .141 & .098 & .131 & 1.447 & .151 \\
\hline & Pelayanan & .270 & .095 & .256 & 2.835 & .006 \\
\hline & NilaiTaksir & .407 & .096 & .472 & 4.253 & .000 \\
\hline
\end{tabular}

a. Dependent Variable: Keputusan Nasabah Menggunakan Produk Gadai Emas

Berdasarkan hasil diatas, diperoleh persamaan regresi sebagai berikut :

$$
\begin{aligned}
& Y: a+\beta_{1} X_{1}+\beta_{2} X_{2}+\beta_{3} X_{3} \\
& Y: 3.138+0,141 X_{1}+0,270 X_{2}+0,407 X_{3}
\end{aligned}
$$

Keterangan :

Y $\quad$ Keputusan nasabah menggunakan produk gadai emas di BSM

a

: Konstanta

$\beta_{1}, \beta_{2}, \beta_{3}$ : Koefisien regresi

$\mathrm{X}_{1} \quad:$ Faktor promosi

$\mathrm{X}_{2} \quad$ : Faktor pelayanan

$\mathrm{X}_{3} \quad$ : Faktor nilai taksiran

Dari persamaan diatas dapat diinterprestasikan sebagai berikut

1) Konstanta

Konstanta sebesar 3.138 artinya apabila variabel faktor promosi, faktor pelayanan, dan faktor nilai taksiran bernilai tetap maka keputusan nasabah menggunakan produk gadai emas di BSM bernilai postif.

2) Faktor Promosi $\left(X_{1}\right)$

Koefisien Regresi $\mathrm{X}_{1}\left(\beta_{1}\right)$ sebesar 0,141 artinya jika variabel faktor promosi meningkat dengan asumsi faktor promosi, faktor pelayanan dan faktor nilai taksiran tetap maka keputusan nasabah menggunakan produk gadai emas di BSM mengalami peningkatan.

3) Faktor Pelayanan $\left(\mathrm{X}_{2}\right)$

Koefisien Regresi $X_{2}\left(\beta_{2}\right)$ sebesar 0,270 artinya jika variabel faktor pelayanan meningkat dengan asumsi faktor promosi, faktor pelayanan dan faktor nilai taksiran tetap maka keputusan nasabah menggunakan produk gadai emas di BSM mengalami peningkatan.

4) Faktor Nilai Taksiran $\left(X_{3}\right)$ 
Koefisien Regresi $\mathrm{X}_{3}\left(\beta_{3}\right)$ sebesar 0,407 artinya jika variabel faktor nilai taksiran meningkat dengan asumsi faktor promosi, faktor pelayanan dan faktor nilai taksiran tetap maka keputusan nasabah menggunakan produk gadai emas di BSM mengalami peningkatan.

\section{b. Pengujian Hipotesis Secara Parsial (Uji t)}

Uji t pada dasarnya menunjukkaan seberapa jauh pengaruh satu variabel independen secara individual menerangkan variasi variabel terikat. Pengujian parsial regresi dimaksudkan untuk mengetahui apakah variabel bebas secara individual mempunyai pengaruh terhadap variabel terikat dengan asumsi variabel yang lain itu konstan.

Pengujian variabel independen secara individu yang dilakukan untuk melihat signifikansi dari pengaruh secara parsial variabel independen terhadap variabel dependen, maksudnya yakni apakah model regresi variabel independen $\left(\mathrm{X}_{1}, \mathrm{X}_{2}\right.$, dan $\left.\mathrm{X}_{3}\right)$ secara parsial berpengaruh signifikan positif terhadap variabel dependen $(\mathrm{Y})$.

Dasar pengambilan keputusan :

Jika nilai sig $<0,05$ maka terdapat pengaruh variabel $\mathrm{X}$ terhadap variabel $\mathrm{Y}$

Jika nilai sig $>0,05$ maka tidak terdapat pengaruh variabel $\mathrm{X}$ terhadap Variabel $\mathrm{Y}$ 


\section{Jumiarni, Moh. Yasin Soumena, Rusnaena}

H0 : Tidak terdapat pengaruh faktor-faktor yang mempengaruhi keputusan nasabah menggunakan produk gadai emas di bank syariah mandiri KCP Polewali

H1 : Terdapat pengaruh faktor-faktor yang mempengaruhi keputusan nasabah menggunakan produk gadai emas di bank syariah mandiri KCP Polewali

Tabel 6

\section{Pegujian secara parsial (uji-t)}

\section{Coefficients $^{\mathrm{a}}$}

\begin{tabular}{|c|c|c|c|c|c|c|}
\hline \multirow{2}{*}{\multicolumn{2}{|c|}{ Model }} & \multicolumn{2}{|c|}{ Unstandardized Coefficients } & \multirow{2}{*}{$\begin{array}{c}\text { Standardized } \\
\text { Coefficients } \\
\text { Beta }\end{array}$} & \multirow[t]{2}{*}{$\mathrm{t}$} & \multirow[t]{2}{*}{ Sig. } \\
\hline & & B & Std. Error & & & \\
\hline \multirow{4}{*}{1} & (Constant) & 3.138 & 1.660 & & 1.891 & .062 \\
\hline & Promosi & .141 & .098 & .131 & 1.447 & 151 \\
\hline & Pelayanan & .270 & .095 & .256 & 2.835 & .006 \\
\hline & NilaiTaksir & .407 & .096 & .472 & 4.253 & .000 \\
\hline
\end{tabular}

a. Dependent Variable: Keputusan Nasabah Menggunakan Produk Gadai Emas

Diketahui nilai sig. untuk pengaruh variabel faktor promosi $\left(\mathrm{X}_{1}\right)$ terhadap nasabah menggunakan produk gadai emas $(\mathrm{Y})$ sebesar $0,151>0.05$ atau artinya bahwa variabel faktor promosi $\left(\mathrm{X}_{1}\right)$ berpengaruh namun tidak signifikan terhadap keputusan nasabah menggunakan produk gadai emas di BSM $(\mathrm{Y})$.

Diketahui nilai sig. untuk pengaruh variabel faktor pelayanan $\left(\mathrm{X}_{2}\right)$ terhadap keputusan nasabah menggunakan produk gadai emas di BSM $(\mathrm{Y})$ sebesar $0,006<0,05$ artinya bahwa variabel faktor pelayanan $\left(\mathrm{X}_{2}\right)$ secara berpengaruh dan signifikan terhadap keputusan nasabah menggunakan produk gadai di BSM $(\mathrm{Y})$.

Diketahui nilai sig. untuk pengaruh variabel sikap $\left(\mathrm{X}_{3}\right)$ terhadap minat masyarakat $(\mathrm{Y})$ sebesar 0,000 >0.05 artinya bahwa variabel nilai taksiran $\left(\mathrm{X}_{3}\right)$ secara berpengaruh dan signifikan terhadap keputusan nasabah menggunakan produk gadai emas di BSM (Y). Pengujian Hipotesis Secara Simultan (Uji F)

Uji $\mathrm{F}$ berfungsi untuk mengetahui apakah variabel independen $\left(\mathrm{X}_{1}, \mathrm{X}_{2}\right.$, dan $\left.\mathrm{X}_{3}\right)$ secara bersama-bersama berpengaruh secara signifikan terhadap variabel dependen $(Y)$. Serta untuk mengetahui apakah model regresi dapat digunakan untuk memprediksi variabel dependen $(\mathrm{Y})$ atau tidak.

Table 7

Pengujian Secara Simultan (Uji-F)

ANOVAa

\begin{tabular}{|l|l|l|l|l|l|}
\hline Model & $\begin{array}{l}\text { Sum of } \\
\text { Squares }\end{array}$ & $\mathrm{df}$ & Mean Square & $\mathrm{F}$ & Sig. \\
\hline
\end{tabular}




\begin{tabular}{|ll|r|r|r|r|r|}
\hline \multirow{4}{*}{1} & Regression & 145.444 & 3 & 48.481 & 36.672 & $.000^{\mathrm{b}}$ \\
& Residual & 126.916 & 96 & 1.322 & & \\
& Total & 272.360 & 99 & & & \\
\hline
\end{tabular}

a. Dependent Variable: Keputusan Nasabah Menggunakan Produk Gadai Emas

b. Predictors: (Constant), Nilai Taksir, Pelayanan, Promosi

Berdasarkan output diatas, perhitungan uji statistik yang dilakukan maka diperoleh nilai

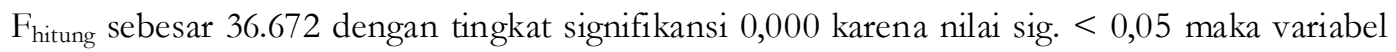
Faktor Promosi, Faktor Pelayanan dan Faktor Nilai Taksiran Mempengaruhi Keputusan Nasabah Menggunakan Produk Gadai Emas di BSM bersama-sama berpengaruh secara simultan sehingga dapat dikatakan bahwa model regresi dapat dipakai untuk memprediksi keputusan nasabah.

\section{c. Korelasi Ganda}

Analisis ini bertujuan untuk mengetahui tingkat keeratan hubungan (simultan) anatara dua atau lebih variabel bebas $(\mathrm{X})$ terhadap variabel terikat $(\mathrm{Y})$. Koefisien ini menunjukkan seberapa besar hubungan yang terjadi antara variabel independen $\left(\mathrm{X}_{1}, \mathrm{X}_{2}\right.$, dan $\left.\mathrm{X}_{3}\right)$ secara serentak terhadap variabel dependen $(Y)$. Nilai $R$ berkisar antar 0 sampai 1 , nilai yang 
mendekati 1 berarti hubungan yang terjadi semakin tinggi, sebaliknya nilai semakin mendekati 0 maka hubungan yang terjadi semakin lemah.

Pedoman untuk memberikan interpretasi koefisien sebagai berikut :

$$
\begin{array}{ll}
\text { Nilai } 0,00-0,20 & =\text { tidak ada korelasi } \\
\text { Nilai } 0,21-0,40 & =\text { korelasi lemah } \\
\text { Nilai } 0,41-0,60 & =\text { korelasi sedang } \\
\text { Nilai } 0,61-0,80 & =\text { korelasi kuat } \\
\text { Nilai } 0,81-1,00 & =\text { korelasi sempurna }
\end{array}
$$

\section{Tabel 8}

Hasil pengujian Koefisien determinasi $\left(\mathbf{R}^{2}\right)$

Model Summary

\begin{tabular}{|l|r|r|r|r|}
\hline Model & \multicolumn{1}{|c|}{$\mathrm{R}$} & R Square & \multicolumn{1}{|c|}{$\begin{array}{c}\text { Adjusted R } \\
\text { Square }\end{array}$} & $\begin{array}{c}\text { Std. Error of } \\
\text { the Estimate }\end{array}$ \\
\hline 1 & $.731^{\mathrm{a}}$ & .534 & .519 & 1.14980 \\
\hline
\end{tabular}

a. Predictors: (Constant), Nilai Taksir, Pelayanan, Promosi

Berdasarkan tabel diatas, hasil uji regresi angka $\mathrm{R}$ sebesar 0,731. Hal ini menunjukkan bahwa terdapat hubungan yang sedang antara variabel independen (X1, X2, dan X3) terhadap variabel dependen $(Y)$.

\section{d. Koefisien Determinasi $\left(\mathbf{R}^{2}\right)$}

Koefisien determinasi digunakan untuk mencari seberapa besar variasi variabel independen dapat menjelaskan secara keseluruhan variasi variabel independen. Koefisien determinasi mengukur seberapa besar pengaruh variabel independen secara keseluruhan terhadap naik turunnya variasi nilai variabel independen

Tabel 4.14

Hasil Pengujian Koefisien Determinasi $\left(\mathbf{R}^{2}\right)$

Model Summary

\begin{tabular}{|l|r|r|r|r|}
\hline Model & \multicolumn{1}{|c|}{$\mathrm{R}$} & R Square & \multicolumn{1}{|c|}{$\begin{array}{c}\text { Adjusted R } \\
\text { Square }\end{array}$} & $\begin{array}{c}\text { Std. Error of } \\
\text { the Estimate }\end{array}$ \\
\hline 1 & $.731^{\mathrm{a}}$ & .534 & .519 & 1.14980 \\
\hline
\end{tabular}

a. Predictors: (Constant), Nilai Taksir, Pelayanan, Promosi 
b. Dependent Variable: Keputusan Nasabah Menggunakan

Produk Gadai Emas

Berdasarkan analisis diatas, diketahui bahwa nilai koefisien determinasi sebesar 0,534 artinya bahwa 53,4 \% nasabah dipengaruhi oleh faktor promosi, faktor pelayanan, dan faktor nilai taksiran. Sedangkan sisanya $46.6 \%$ dipengaruhi oleh faktor lain yang tidak termasuk dalam penelitian ini.

\section{Pembahasan}

Hasil pengujian menunjukkan variabel faktor promosi, faktor pelayanan dan faktor nilai taksiran secara simultan berpengaruh signifikan terhadap keputusan nasabah menggunakan produk gadai emas di BSM, kemudian hasil pengujian parsial menunjukkan bahwa variabel faktor pelayanan dan faktor nilai taksiran berpengaruh dan signifikan terhadap keputusan nasabah menggunakan produk gadai emas di BSM, sedangkan variabel faktor promosi dan faktor nilai taksiran berpengaruh namun tidak signifikan terhadap keputusan nasabah menggunakan produk gadai emas di BSM.

Adapun faktor-faktor yang mempengaruhi nasabah menggunakan produk gadai emas di bank syariah mandiri sebagai berikut : 


\section{Jumiarni, Moh. Yasin Soumena, Rusnaena}

a. Pengaruh Faktor Promosi Terhadap Keputusan Nasabah Menggunakan Produk Gadai Emas di BSM

Promosi adalah upaya perusahaan mempengaruhi para pelanggan atau konsumen agar mau menggunakan produk atau jasa yang ditawarkan oleh perusahaan. Promosi meliputi unsur-unsur pemberian informasi dan pengaruh terhadap perilaku pelanggan.

Hasil pengujian secara parsial atau uji t menunjukkan bahwa variabel faktor promosi berpengaruh namun tidak signifikan terhadap keputusan nasabah menggunakan produk gadai emas di BSM. Hal ini menunjukkan bahwa faktor promosi dari pihak bank kepada nasabah tidak terlalu mempengaruhi keputusan nasabah menggunakan gadai emas di BSM.

Hasil pengujian menunjukkan diketahui nilai sig. untuk pengaruh variabel motivasi $\left(\mathrm{X}_{1}\right)$ terhadap minat masyarakat $(\mathrm{Y})$ sebesar $0,151>0.05$ artinya bahwa variabel faktor promosi $\left(\mathrm{X}_{1}\right)$ secara parsial berpengaruh namun tidak signifikan terhdap keputusan nasabah menggunakan produk gadai emas di BSM (Y).

b. Pengaruh Faktor Pelayanan Terhadap Keputusan Nasabah Menggunakan Produk Gadai Emas

Pelayanan dapat diartikan sebagai upaya perusahaan mempengaruhi para pelanggan atau konsumen agar mau menggunakan produk atau jasa yang ditawarkan oleh perusahaan.

Hasil pengujian secara parsial atau uji t menunjukkan bahwa variabel faktor pelayanan berpengaruh dan signifikan terhadap keputusan nasabah menggunakan produk gadai emas di BSM. Hal ini menunjukkan bahwa faktor pelayanan dari pihak bank kepada nasabah tidak mempengaruhi keputusan nasabah menggunakan gadai emas di BSM.

Hasil pengujian menjukkan diketahui nilai sig. untuk pengaruh variabel faktor pelayanan $\left(\mathrm{X}_{2}\right)$ terhadap keputusan nasabah $(\mathrm{Y})$ sebesar $0,006<0.05$ artinya bahwa variabel faktor pelayanan $\left(\mathrm{X}_{2}\right)$ secara parsial berpengaruh dan signifikan terhadap keputusan nasabah menggunakan gadai emas di BSM (Y).

c. Pengaruh Faktor Nilai Taksiran Terhadap Keputusan nasabah Menggunakan Produk Gadai Emas di BSM

Faktor nilai taksiran adalah nilai/harga perkiraan tertentu yang akan dijadikan jaminan yang didasarkan pada harga jadi, pasar dan peraturan yang berlaku pada masa tertentu.

Hasil pengujian secara parsial atau uji t menunjukkan bahwa variabel faktor nilai taksiran berpengaruh dan signifikan terhadap keputusan nasabah menggunakan produk gadai emas di BSM. Hal ini menunjukkan bahwa faktor nilai taksiran dari pihak bank kepada nasabah tidak mempengaruhi keputusan nasabah menggunakan gadai emas di BSM. 
Hasil pengujian menunjukkan diketahui nilai sig. untuk pengaruh variabel faktor nilai taksiran $\left(\mathrm{X}_{3}\right)$ terhadap keputusan nasabah $(\mathrm{Y})$ sebesar $0,000<0.05$ artinya bahwa variabel faktor nilai taksiran $\left(\mathrm{X}_{3}\right)$ secara parsial berpengaruh dan signifikan terhadap keputusan nasabah menggunakan produk gadai emas $(\mathrm{Y})$.

Berdasarkan hasil pembahasan sebelumnya mengenai faktor promosi, faktor pelayanan dan faktor nilai taksiran terhadap keputusan nasabah menggunakan produk gadai emas di BSM dengan tujuan untuk mengetahui pengaruh signifikan faktor promosi, faktor pelayanan dan faktor nilai takiran serta untuk mengetahui variabel yang berpengaruh dominan terhadap keputusan nasabah menggunakan produk gadai emas di BSM.

Dari hasil pembahasan menyatakan bahwa keputusan nasabah menggunakan produk gadai emas di BSM di pengaruhi oleh variabel faktor pelayanan dan faktor nilai taksiran dimana keputusan nasabah menggunakan produk gadai emas di BSM sangat berpengaruh dan signifikan pada sebuah bank, keputusan nasabah menggunakan produk gadai emas pada Bank Syariah Mandiri tersebut dapat meningkatkan kelangsungan hidup sebuah bank. Usaha untuk melakukan pelayanan dan nilai taksiran terhadap produk gadai emas tidak bisa di lakukan sekaligus tetapi melalui beberapa tahapan mulai dari mencari nasabah dan rekan kerja. Dengan pentingnya faktor pelayanan dan faktor nilai taksiran terhadap keputusan 


\section{Jumiarni, Moh. Yasin Soumena, Rusnaena}

nasabah menggunakan produk gadai emas di BSM maka pihak bank juga harus memperhatikan faktor faktor promosi sehingga mendorong nasabah menggunakan produk gadai emas di BSM.

Hal ini menunjukkan bahwa variabel faktor promosi, faktor pelayanan dan faktor nilai taksiran berpengaruh secara simultan terhadap keputusan nasabah menggunakan produk gadai emas di BSM. Hasil penelitian ini menunjukkan bahwa peningkatan terhadap ketiga variabel tersebut berpengaruh dan signifinikan terhadap keputusan nasabah menggunakan produk gadai emas di BSM. Kemudian variabel faktor pelayanan dan faktor nilai taksiran berpengaruh secara parsial terhadap keputusan nasabah menggunakan produk gadai emas di BSM. Sedangkan variabel faktor promosi tidak begitu berpengaruh terhadap keputusan nasabah menggunakan produk gadai emas di BSM. Jadi, keputusan nasabah dipengaruhi oleh suatu variabel tersebut dalam hal ini faktor pelayanan dan faktor nilai taksiran.

Dari hasil perhitungan uji $\mathrm{t}$ atau secara parsial, faktor yang paling dominan berpengaruh secara simultan diantara faktor promosi, faktor pelayanan dan nilai taksiran dari hasil penelitian ini adalah faktor pelayanan dan faktor nilai taksiran yang sangat berpengaruh dominan secara simultan terhadap keputusan nasabah menggunakan produk gadai di BSM.

Dari sisi frekuensinya antara variabel faktor promosi, faktor pelayanan dan faktor nilai taksiran yang berpengaruh dominan terhadap keputusan nasabah menggunakan produk gadai emas di BSM adalah faktor pelayanan dan faktor nilai taksiran. Dibuktikan dengan uji parsial atau uji t dengan nilai sig 0,006 dan $0,000<$ dari probability yakni 0,05 .

\section{Kesimpulan}

Berdasarkan hasil penelitian dan pembahasan yang telah dijelaskan, maka dapat ditarik kesimpulan, yaitu:

Secara simultan dari ketiga faktor promosi, faktor pelayanan dan faktor nilai taksiran berpengaruh dan signifikan terhadap keputusan nasabah menggunakan produk gadai emas di BSM.. Kemudian faktor pelayanan dan faktor nilai taksiran berpengaruh secara parsial terhadap keputusan nasabah menggunakan produk gadai emas di BSM. Sedangkan faktor promosi tidak begitu berpengaruh terhadap keputusan nasabah menggunakan produk gadai emas di BSM. Jadi, keputusan nasabah dipengaruhi oleh suatu variabel tersebut dalam hal ini faktor pelayanan dan faktor nilai taksiran. 


\section{Daftar Pustaka}

\section{Buku}

Al-Arif, M. Nur Rianto. 2010. Dasar-dasar Pemasaran Bank Syariah. Bandung: Alfabeta.

Al-Asqalani, Ibnu Hajar. 2010. Fathul Baari Syarah Shahih Al Bukhari. Cet. II; Jakarta: Pustaka Azzam. Ascarya. 2006. Akad \& Produk Bank Syariah. Jakarta: Raja Garfindo Persada.

Antonio, Muhammad Syafi'i. 2011. Bank Syariah dan Teori ke Praktek. Jakarta: Gema Insani Press.

—. Bank Syariab: Suatu Pengenalan Umum.

Anggawirya, Erham dan Audi C. 2002. Kamus Lengkap Bahasa Indonesia.Surabaya: Indah Surabaya.

A. Djazuli. 2002. Lembaga-Lembaga Perekonomian Umat. Bandung: Raja Grafindo Persada.

Al Zuhaili, Wahbah 1989. jilid VI al Figh al Islam wa Adillatubu Damaskus Dar al Fikr.

Basyir, Ahmad Azhar. 1983. Hukum Islam tentang Riba dan Utang-Piutang Gadai. Bandung: Al-Ma'arif.

Barata, Atep Adya. 2003. Dasar-Dasar Pelayanan Prima. Jakarta: Elex Media Computindo.

Banco, Volume 1, Mei 2019 


\section{Jumiarni, Moh. Yasin Soumena, Rusnaena}

Bungin, Burhan. Metode Penelitian Kuantitatif. Jakarta:Kencana.

Depertemen Agama RI, 2004. Al-Quran dan Terjemahannya. Bandung : CV Penerbit J-ART.

Departemen Agama. Alquran dan Terjemahan.

Fatwa DSN No. 25/ DSN-MUI/III/2002 tentang Rahn.

Fatwa Dewan Syariah Nasional No.25/DSN-MUI/III/2002 tentang Rahn Emas.

Hadi, Trisno. 1995. Metodologi Research Jilid 2. Cet.XXIV. Yogyakarta: Andi Pffset.

Haroen, Nasrun. 2000. Fiqh Muamalah. Jakarta: Gaya Media Pratama.

Kasmir. 2008. Bank dan Lembaga Keuangan Lainnya. Jakarta: PT Raja Grafindo Persada. 2005. Pemasaran Bank. Jakarta: Prenada Media.

Kementrian agama Sekolah Islam Negeri Tulungagung. 2013. Pedoman Penyusunan Skiripsi Sekolah Tinggi Agama Islam Negeri (STAIN) Tulungagung.

Kotler, Philip. 2004. Mananjemen Pemasaran, Terj. Hendra Teguh, Benyamin Molan, dan Rony A. Rusli. Jilid 2. Jakarta: Index Kelompok Gramedia.

Kristianto, Paulus Lilis. 2011. Psikologi Pemasaran. Yogyakarta: CAPS.

Lupiyoadi, Rambat dan A. Hamdani. 2006. Manajemen Pemasaran Jasa. Jakarta: Salemba Empat.

McCarthy, E. Jerome. 1993. Dasar-Dasar Pemasaran. Jakarta: Erlangga.

Muhammad 'Uwaidah, Syaikh Kamil. 2000. Fiqih Wanita. Cet. Ke IV. Jakarta; Pustaka Al-Kautsar.

NH, Muhammad Firdaus, dkk. 2005. Mengatasi Masalah dengan Pegadaian Syariah, Jakarta: RENAISAN Anggota IKAPI.

Pandia, Frianto, dkk. 2004. Lembaga Keuangan. Jakarta: Rineka Cipta.

Penyusun,Tim. 2013. Pedoman Penulisan Karya Ilmiah (Makalah dan Skripsi). Parepare: STAIN.

Rasyid, Ibnu. 1996. Bidayatul Mujahid. jilid III. Semarang: Asy-Syifa.

Siregar, Syofian Ir. M.M, Metode Penelitian Kuantitatif.

- 2015. Statistik Parametrik untuk Penelitian Kuantitatif Dilengkapi dengan Perhitungan Manual dan Aplikasi SPSS Versi 17. Cet.3; Jakarta: PT Bumi Aksara.

- Statistik Parametrik untuk Penelitian Kuantitatif Dilengkapi dengan Perbitungan Manual dan Aplikasi SPSS Versi 17.

Siddiq, Muhammad Najatullah. 1984. Bank Islam. cet 1. Bandung; Pustaka.

Soehardi, Sigit. 1999.Pengantar MetodologiPenelitian Sosial-Bisnis-Manajemen. Yogyakarta : Luqman Offset.

Soemitra, Andri. 2009. Bank dan Lembaga Keuangan Syariah. Jakarta: Kencana Prenamedia Group. 
Sudarsono, Heri. 2003. Bank dan Lembaga Kenangan Syariah. Yogyakarta: Ekonisisa, Ed ke-2.

Sugiyono. 2012. Metode Penelitian Pendidikan Pendekatan Kuantitatif, Kualitatif dan R\&D. Bandung: Alfabeta.

Surat Edaran Bank Indonesia Nomor 14/7/Dpbs Tentang Produk Qardh Beragunan Emas bagi Bank Syariah dan Unit Usaha Syariah.

Surat Edaran No. SE: S. 022-DIR/MDM/05-2013 Tentang Petunjuk Pelaksanaan Qardh Beragun. Jakarta, 3 Mei 2013.

Syafe'i, Rahmat. 2004. Fiqh Muamalah. Bandung: Pustaka Setia.

Tanzeh, Ahmad dan Suyitno. 2006. Dasar-dasar Penelitian Surabaya: Lembaga Kajian Agama dan Filsafat (ELKAF),

Thantawi, Muhammad Sayyid. 1997. Muamalah Al-Bunuk Wa Abkumuba' al-Syariyyah. Mesir Dar Nahdhah.

Tjiptono, Fandy. 1997 Stategi Pemasaran.Yogyakarta: Penerbit Andi.

2007. Perspektif Manajemen dan Pemasaran Kontemporer. Cet. Pertama. Yogyakarta: Andi Offset.

Usman, Rachmadi. ,2002. Aspek-aspek Hukum Perbankan Islam di Indonesia. Bandung: PT. Citra Aditya Bakti.

Widyaningsih, dkk. 2005. Bank dan Asuransi Islam di Indonesia. Jakarta. 


\section{Jumiarni, Moh. Yasin Soumena, Rusnaena}

Wibobo, Edy dan Untung Hendy Widodo. Mengapa Memilih Bank Syariah?

Ya'qub, Hamzah. Kode Etik Dagang Menurut Islam.

Zuriah, Nurul. Metodologi Peneltian Sosial dan Pendidikan.

\section{Skripsi :}

Damanhur. 2011. Pengaruh Jumlab Taksiran dan Uang Pinjaman Terhadap Laba Bersih pada Perum Pegadaian Syariah Kota Lhokseumawe. Volume 9 Nomor 2. Maret.

Susilowati, 2018. Pelaksanaan Gadai Dengan Sistem Syariah di Perum Pegadaian Semarang.

\section{Website:}

Priady, Wahyu. 2018. "Uji Hipotesis: Uji Parsial atau Uji t dengan Menggunakan SPSS 20.” Blog Wabyu Priady.http://jempolbayek.blogspot.co.id/2015/11/uji-hipotesis-uji-parsial-atau-uji-t.html?m=1.

Priady, Wahyu. 2018. “Uji Hipotesis: Uji Simultan atau Uji F dengan Menggunakan SPSS 20.” Blog Wabyu Priady. $\quad$ http://jempolbayek.blogspot.co.id/2015/11/uji-hipotesis-uji-simultan-atau-ujif.html? $\mathrm{m}=1$.

Wijaya, Pelaksanaan Perjajian Gadai Emas Berdasarkan Prinsip Syariah (Studi Pada PT. Bank BRI Syariah Cabang Tanjung Karang), dalam www.google.co.id. Akses pada tanggal 25 Mei 2018. 